\title{
Managing Common Security: Indonesia-China Cooperation in Handling Covid-19 Pandemic
}

\author{
Marten Hanura ${ }^{1}$, Hermini Susiatiningsih ${ }^{2}$, Tri Cahyo Utomo ${ }^{3}$, Aulianisa Rahma Dyah \\ Rusyadi $^{4}$, Sapen Sartika Unyi Putri ${ }^{5}$ \\ \{marten.h@live.undip.ac.id ${ }^{1}$, herminisusi@lecturer.undip.ac.id ${ }^{2}$, tricahyoutomo@gmail.com ${ }^{3}$, \\ aulianisa.rahma@gmail.com ${ }^{4}$, upsapensartika@gmail.com ${ }^{5}$ \} \\ Department of International Relations, Universitas Diponegoro ${ }^{1,2,3,4,5}$
}

\begin{abstract}
The presence and spread of Covid-19 virus to every corner of the world, including Indonesia, caused a massive change in almost every aspect, especially the global economy. Human activities had to be restricted as a preventive action to avoid the spread of the virus and slowly reduce the country's economic stability. As one of the countries that handled Covid-19 pandemic, China is cooperating with other countries that experienced a similar crisis, including Indonesia. It shows that in dealing with pandemic, countries need to cooperate. This article discusses the development of bilateral relations between China and Indonesia in Responding to Covid-19 pandemic and its impact on the two countries. By using the International Cooperation approach and Bilateralism created the main argument that Indonesia and China have created cooperation in dealing with mutual crises and to revive from the downturn caused by Covid-19 pandemic. Various collaborations began to be carried out and experienced rapid development, not only in the health sector but also in other fields such as economics and infrastructures.
\end{abstract}

Keywords: China; Indonesia; Common Security; Bilateral Cooperation; Covid-19 Pandemic

\section{Introduction}

The outbreak of Covid-19 in China at the end of 2019, followed by the widespread of the virus to various parts of the world, did present an unexpected challenge for the global community. It is undeniable that China, as one of the countries to fight against the virus even fell in the early period of the emergence of Covid-19. Several countries reach out by sending several medical supplies to China. Indonesia was one of the countries that showed their support for China during the early Period of the emergence of Covid-19. Quoting from the statement of the Ministers of Foreign Affairs, Retno Marsudi, Indonesia was on a mission to evacuate Indonesian citizens in Hubei, China, and also help in providing medical equipment, such as face masks and surgical units which were directly distributed through the Hubei Charity Foundation (Republika, 2020). President Joko Widodo claimed to have offered direct assistance to President Xi Jinping via telephone regarding the handling of covid19 (Tempo, 2020). 
This article answers why Indonesia and China are Collaborating in dealing with Covid-19, and the form of bilateral cooperation between both countries. This article discusses the development of bilateral relations between Indonesia and China in handling Covid-19 pandemic, and explains the aspects of cooperation between the two countries. Besides that, this article also explained the development of the global pandemic situation, especially in Indonesia and China as the main research focus and analysed the cooperation as a of form foreign policy created by both countries. The research method used in compiling this article utilizes primary and secondary data. Researchers use data or information contained in books, journals, magazines, and newspapers to compile this research. Various relevant data are selected, classified, and analyzed to seek relations between one data or information with the other.

As it is known, China has risen to become one of the global economic powers currently in fierce competition with the United States. To strengthen China's position in the world economy, it tries to expand its markets by establishing good relations with neighboring countries such as South Korea, Japan, Russia, and ASEAN countries (Umagapi, 2017). The negative impact on the economic sector due to Covid-19 also makes China's Belt and Road Initiative (BRI) projects unlikely to be continued. Therefore, China is now focusing its attention on the Health Silk Road (HSR), which emphasizes BRI'S countries health programs. HSR aims to strengthen cooperation in the health sector between China and the BRI countries to deal with public health problems such as Covid-19. Regarding the HSR mechanism between China and ASEAN countries, China tends to prioritize bilateral relations. It was chosen because each country has unique challenges and needs. Therefore almost all projects are negotiated bilaterally (Chow-bing, 2020).Vaccination can be one of the main key to restoring economies worldwide, including China and Indonesia. In ASEAN countries such as Indonesia, vaccines are seen as one of the most important solutions to defeat Covid-19, considering that preventive measures and lockdowns are very difficult to implement. Indonesia's need for vaccines matches with China's condition which can produce the first generation of Covid-19 vaccines on a large scale (Jetin et al., 2020).

Previous studies that are relevant to this research can be seen in Vermonte et al (2020) entitled "Enhancing International and Regional Cooperation to Mitigate the Effects of the COVID-19 Pandemic: A View From Indonesia" discussing the efforts that Indonesia can make in dealing with two important aspects due to the impact of the Covid-19 pandemic, namely the economy and health. In addition, the article that was written by Djalante et al (2020) entitled "COVID-19 and ASEAN responses: Comparative policy analysis" discusses the response of ASEAN member countries regarding the handling of the COVID-19 pandemic with "One Vision, One Identity, One Community"., ASEAN cooperation has expanded to include disaster response throughout the region, framed as "One Asean, One Response".

Furthermore, an article from Waluyo et al (2020) entitled "Indonesia Defense Diplomacy in Enhancing Indonesia-China Defense Cooperation" states that global politics has changed the polarity and distribution of power in the last two decades. This study analyzes the realization of Indonesia's defense diplomacy carried out to enhance Indonesia-China defense cooperation. From the previous research above, there is a gap not yet research that discusses the cooperation between Indonesia and China in dealing with the COVID-19 pandemic that a novelty in this research article.

Using the International Cooperation approach and Bilateralism, this article explained the development between China and Indonesia cooperation in handling the pandemic caused by Covid-19. This article will be divided into three main parts: Introduction that consist of explanation about the topic, the main argument to the article structure, and the body of article 
that consists of the research findings analyzed with International Approach and Bilateralism and conclusion.

\section{Discussion}

Cooperation between Indonesia and China in tackling the COVID-19 pandemic is academically seen by using the approach of International Cooperation and Bilateralism. Cooperation is a series of relations that are not based on violence or coercion and are legalized. Cooperation occurs because of the adjustment of behavior by actors as a response and anticipation of the choices made by other actors. An important key in cooperation is the extent to which each person believes the other party. The main issue of the cooperation approach is the fulfillment of self-interest, where the results will benefit both parties that obtained through cooperation, rather than trying to fulfill their own interests by trying alone or by competing (Dougherty\&Pflatzgraff, 1995). There are several reasons why countries cooperate:1). To increase economic welfare. Many countries cooperate with other countries to reduce the cost in producing a product that is needed; 2). Improve efficiency related to cost reduction; 3). Common security problems; 4). Reduce adverse losses caused by the action of certain countries that impact other countries. Based on several reasons that underlie a country to establish cooperative relations with other countries, the cooperation between Indonesia and China occurred due to a common security threat: Covid-19 Pandemic.

Whereas bilateralism is a political, economic, or cultural relations between two sovereign states. When countries recognize each other as a sovereign state and agree to hold a diplomatic relation, both create bilateral relations. Countries that have bilateral relations will exchange diplomatic agents such as ambassadors to facilitate dialogue and cooperation. Cooperation will lead to a mutual agreement in the form of provisions that must be adhered together to harmonize relations between the two. The agreed agreement are policies that will benefit the two countries who cooperate in accordance with the goals of each country, such as bilateral cooperation between Indonesia and China in dealing with Covid-19.

\subsection{Forms of Cooperation Between China and Indonesia in Handling the Covid-19 Pandemic}

As a country that was assumed as the starting point and epicenter of the spread of Covid19 throughout the world, China certainly has an earlier handling mechanism thean other countries affected by the spread of Covid-19. Several other collaborations are also carried out between the two countries as an effort to prevent and overcome the spread of Covid-19.

\section{a) Vaccine Diplomacy}

Wednesday, January 13, 2021, Indonesian Minister of Foreign Affairs, Retno Marsudi, visited by the Chinese Minister of Foreign Affairs/State Councillor, Y.M. Wang Yi in Jakarta. Regarding the issue of health cooperation, Indonesian Foreign minister emphasized that it was essential to continue regional health cooperation in ASEAN. Especially to follow up on China's various commitment in handling the pandemic, such as USD 5 million to support the Public Health Cooperation Initiative: Program on Public Health Emergency Preparedness Capacity (PROMPT) and a commitment of USD 1 million for the ASEAN Covid-19 Response Fund (The Ministry of Foreign Affairs of Republic of Indonesia, 2021). 
Efforts to develop vaccines by bilateral cooperation with China's government are held through Sinovac company. He also added that the government, through Eijkman Biomolecular Institute and Airlangga University, was also continuing to work on studies to find the vaccine. Research conducted by the Eijkman Biomolecular Institute and Airlangga University, focuses more on the corona virus's character that is spreading in Indonesia (Kompas, 2020).

\section{b) Aid for Medical Equipment and Personal Protective Equipment (PPE)}

Since the early days of the pandemic, Indonesia and China have collaborated on health to provide of diagnostic, therapeutic, and vaccine tools. In addition, the two countries are also committed to increasing the independence of the drug industry, medicinal raw materials, and medical devices in Indonesia. This assistance consists of Covid-19 test kits, N95 masks, surgical masks, medical protective clothing, portable ventilators, etc. These medical supplies will be used to prevent and control of the Covid-19 outbreak within Indonesia through Badan Nasional Penanggulangan Bencana (Liputan6, 2020).

Ambassador Xiao Qian said that some of the second batch of aids from the Chinese government had arrived in Indonesia. He also added that his country had assisted in various sectors of Indonesia through various channels, including political parties, local governments, and companies. In addition, the Chinese Embassy is also said to provide assistance to relevant parties in Indonesia to the best of their ability (Liputan6, 2020).

\subsection{Development of China-Indonesia Bilateral Cooperation in Handling the Covid-19 Pandemic}

As previously explained, China and Indonesia's diplomatic relations can be said to have progress amid the spread of the Covid-19 pandemic. Since the beginning of the pandemic the two countries have sent signals of good collaboration to overcome it. Ever since the pandemic began to spread, President Joko Widodo and President Xi Jinping have had three telephone conversations to discuss efforts to combat the Covid-19 pandemic and to maintain better Indonesia China bilateral relations (The Ministry of Foreign Affairs of The People's Republic of China, 2021).

As China is going through the most challenging times battling the pandemic, President Jokowi has expressed his support and sympathy through a telephone conversation with President Xi Jinping. In addition, the Indonesian government also sent medical supplies to China using a plane which was then used to evacuate Indonesian citizens in Wuhan. Indonesia turn which was then faced with the fight against the pandemic, China through President Xi Jinping, also expressed sympathy and support for Indonesia. This China's support took the form of two waves of medical aid assistances including nucleic acid test reagents, masks, protective clothing and portable ventilators(Tiongkokdaily, 2020).

The total value of donations made by the government and Chinese companies has reached USD 10 million. Meanwhile, regarding medical equipment, China has donated an additional 100,000 test kits, 70.00 PPE, 70.000 protective masks, and 1.3 million surgical masks (Kedutaan Besar Republik Rakyat Tiongkok di Republik Indonesia, 2020). Still from the health sector, the collaboration between China and Indonesia can also be seen from the success of three video conferences related to Covid-9, which Chinese and Indonesian medical experts attended. This conference was first held on April 22, 2020, and it was filled with discussions related to the diagnosis and treatment of Covid-19 patients. Furthermore, in this online conference, health experts from both sides discussed diagnostic criteria, therapeutic 
drugs, drug usage criteria, virus variations, and vaccine development (The Ministry of Foreign Affairs of The People's Republic of China, 2020).

The relations between China and Indonesia were even more successful with the cooperation in the procurement of vaccines agreed by the two countries in August 2020. This agreement was announced through the statement from the Indonesian Minister of Foreign Affairs, Retno Marsudi, that stated Indonesia had made two agreements related to vaccines in which Bio Farma, cooperated with Sinovac to provide the availability of vaccines(The Ministry of Foreign Affairs of Republic of Indonesia, 2020).

On December 6, 2020, Indonesia received 1.2 million doses of Sinovac vaccines for the first time. The second batch of 1.8 million doses of Sinovac vaccines arrived on December 31, 2020. On January 12, 2021, the third batch of Sinovac vaccine arrived with 15 million doses of vaccines, and the forth batch arrived on February 2, 2021, with a total of 10 million doses. Meanwhile, on March 26, 2021, Sinovac vaccines were sent to fulfill the vaccination needs in April and May for 16 million doses of vaccines (Cabinet Secretariat of The Republic of Indonesia, 2021).

In addition to cooperation in the health sector Indonesia and China cooperation also established in other fields such as economy, infrastructure, and technology. Cooperation in this field is intended to overcome and recover the economy from Covid-19 pandemic impact. Several collaborative projects carried out by the two countries, such as Jakarta-Bandung highspeed rail and Regional Comprehensive Economic Corridor, have reportedly made steady progress after it was delayed. The two countries agreed to spur economic growth through digital sectors such as 5G, artificial intelligence, big data, and cloud computing. The two countries also agreed to deepen cooperation in the fields of tourism, education and technological innovation (The Ministry of Foreign Affairs of The People's Republic of China, 2021).

2.3 Strengths and Weakness of China-Indonesia Bilateral Cooperation on Facing Covid19 Pandemic

From various forms of cooperation that China and Indonesia have intensified during Covid-19 pandemic of course, there will be some advantages and disadvantages from the implementation of these cooperations, both that have been felt or may occur in the future. The advantages that definitely can be felt are from health sector, where Indonesia's medical needs such as personal protective equipment (PPE) especially for medical personnel, various types of medical masks such as N95 and surgical masks, disposable gloves, special medical glasses, ventilators, and rapid test equipment almost fulfilled. The assistance in health sector was also continued with the provision of diagnostic, therapeutic tools as well as Sinovac and Sinopharm vaccines (CNN Indonesia, 2020).

The benefits obtained by China with the provision of health logistic assistance and vaccines could be seen as China's effort to slowly restore it's good image starting from the region first and hoping to make its image better internationally. When Indonesian start using Sinovac Covid-19 vaccine from China, especially the first person who tried the vaccine was President Joko Widodo followed by other officials, could be seen as China's marketing strategy for their vaccines. This way, other Muslim-majority countries will begin to be interested and trust the safety and halalness of China's vaccines (ABC News, 2021).

In addition to the benefits that can be felt directly from the cooperation between China and Indonesia during this pandemic mentioned previously, the benefits for the future have also begun to be seen. This makes cooperation in the economic sector increasingly heading in a 
more clear direction. With global economic conditions trying to bounce back, Indonesia's exports to China in 2020 increased by around 10\%. A significant increase was seen in Indonesia's steel export. Indonesian Minister of Foreign Affairs, Retno Marsudi, also plans to further expand Indonesia's access to the market in China especially for Indonesia's leading export commodities such as palm oil, tropical fruits, swiftlet nests and marines fishes (The Ministry of Foreign Affairs of Republic of Indonesia, 2021).

For China, this development project is an essential investment for expanding China's market in Indonesia. Moreover, the Belt and Road Initiative (BRI) which will be further intensified will also benefit the Chinese Yuan. Since the beginning of BRI's entry to Indonesia, China's Yuan has also started to become the currency used by China in investing and trading. In 2018, the value of Yuan in the Indonesian market had reached around Yuan 2018 billion, which is equivalent to Rp 439 trillion, and it is equal to $63 \%$ of the Indonesian market value (The Conversation, 2020).

If we look at the disadvantages as a result of Indonesia's bilateral cooperation with China in handling Covid-19 pandemic it is more likely about the impact of long-term losses that Indonesia may feel in the economic field as a result of China's project in Belt and Road Initiative (BRI). If the development project will be even more intensive, there will be even more development plans in the future. This will make Indonesia owe a lot to China (CNN Indonesia, 2018). Furthermore, if The Indonesian government is unable to empower Indonesian workers who have received a lot of training and knowledge transfer from Chinese experts, then Indonesia will still depend on Chinese workers on future development projects.

\section{Conclusion}

The Covid-19 virus has now spread throughout the world, including Indonesia. It causes the existing countries to experience significant changes in almost every aspect, especially health and economy. China, as one of the countries that faced Covid-19 has continuously cooperated with other Asian countries, especially Indonesia. China and Indonesia will focus their cooperation on economic and health issues especially regarding vaccines, medical supplies, and medicines. The emphasis on cooperation in the health sector aims to restore the economy of each country. This is related to China's desire to strengthen its economic position which causes China to need Indonesia as one of its trading partners in ASEAN. Indonesia depends on imports of goods from China and needs China as their main foreign market.

The cooperation between the two helped Indonesia to rise from the Covid-19 pandemic. Sinovac vaccine assistance in millions of doses is undoubtedly one of the Indonesian government's main efforts to prevent the spread of Covid-19. Various medical equipment assistance also helps Indonesia in handling Covid-19 patients. The advantage that China gains from the cooperation between the two are China's reputation is improving again and becoming a market for China's Sinovac vaccine, which was previously doubted for its halalness and effectiveness. The closer relations between Indonesia and China led to an increase in economic and infrastructure cooperation, which slowly increased the pace of trade between the two countries. The BRI projects, which were initially being postponed are also re-run and causing the use of Yen to increase. The disadvantage of this cooperation is that Indonesia's debt to China is increases due to various health, economic and infrastructure projects. It also increases Indonesia's dependence on Chinese aid. The increasing use of Yuan in the Indonesian market makes Indonesia face the risk of a surge in imported goods from China 
which causes local Indonesian products to compete with Chinese products in the domestic market

\section{Acknowledgement}

Authors would like to thank all parties involved and contributing to this research, especially Faculty of Social and Political Sciences, Universitas Diponegoro. In addition, the authors also thank the research assistants who have helped in this research, namely Nurul Husna, Nabilla Rahma Sardi, Endah Tarwiyani and Ratu Fadilah Audzitni Rao.

\section{References}

[1] ABC News. 2021. Apakah Indonesia hanya menjadi Sarana Pemasaran Tiongkok dalam Kerja Sama [Online] Retrieved from: https://www.abc.net.au/indonesian/2021-01-28/ada-apa-dibalikkerjasama-vaksin-antara-Tiongkok-dan-indonesia/13069868.

[2] Antaranews. 2021. Indonesia offers to become vaccine hub for Southeast Asia : FM. [Online] Retrieved from: Antaranews.com: https://en.antaranews.com/news/171586/indonesia-offers-to-become-vaccine-hub-forsoutheast-asia--fm.

[3] Chow-bing, N. 2020. "COVID-19, Belt and Road Initiative and the Health Silk Road". Friedrich Ebert Stiftung (October 2020):5-20.

[4] CNN Indonesia. 2018. Kebijakan Belt and Road Tiongkok Sebabkan Utang Besar. [Online]

Retrieved from https:/www.cnnindonesia.com/ekonomi/20180902164934-92326974/kebijakan-belt-and-road-Tiongkok-sebabkan-utang-besar.

[5] CNN Indonesia. 2020. Tiongkok Tanya Kebutuhan RI, Prabowo Kirim Daftar Alkes Corona. [Online] Retrieved from https://www.cnnindonesia.com/nasional/20200323160659-20-486125/Tiongkok-tanyakebutuhan-ri-prabowo-kirim-daftar-alkes-corona.

[6] CNN Indonesia. 2021. Kebangkitan Ekonomi Tiongkok Bakal Dongkrak Nilai Ekspor RI. [Online] Retrieved from https://www-cnnindonesiacom.cdn.ampproject.org/v/s/www.cnnindonesia.com/ekonomi/20210416120117-532630762/kebangkitan-ekonomi-Tiongkok-bakal-dongkrak-nilai-ekspor-ri.

[7] Databoks. 2020. Nilai Perdagangan 5 Negara Mitra Terbesar Indonesia, Databoks. [Online] Retrieved from https://databoks.katadata.co.id/datapublish/2020/02/25/nilaiperdagangan-5-negara-mitra-terbesar-indonesia.

[8] Djalante, R., Nurhidayah, L., Van Minh, H., Phuong, N., Mahendradhata, Y., Trias, A., Lassa, J., \& Miller, M. A. 2020. "COVID-19 and ASEAN responses: Comparative policy analysis". Progress in Disaster Science, 8:100129.

[9] Doughtery, J.E \& R.L. Pfaltzgraf Jr .2021. Contenting Theory of International Relations: A Comprehensive Survey. New York: Longman

[10] Global Times. 2021. Indonesia to focus on economic and health cooperation, seek support from Tiongkok on regional stability: ambassador, Global Times. [Online] Retrieved from https:/www.globaltimes.cn/page/202101/1213171.shtml.

[11] Jetin, B. et al. 2020. "Research Report on ASEAN-China Cooperation in the Fight 
against Covid-19". NACAI International Symposium University of Yangon (Centennial) 4 (21 November 2020):5-46.

[12] Kompas. 2020. Tiongkok Bantu Indonesia, Prabowo : Ini Adalah Bentuk Kerjasama Internasional. [n.d.). [Online] Retrieved from https:/www.kompas.tv/article/72730/Tiongkok-bantu-indonesia-prabowo-ini-adalahbentuk-kerjasama-internasional.

[13] Kompas. 2020. Kembangkan vaksin COVID-19, Indonesia Jalin Kerja Sama Dengan Tiongkok. [Online] Retrieved from https://nasional.kompas.com/read/2020/06/12/06092421/kembangkan-vaksin-Covid19-indonesia-jalin-kerja-sama-dengan-Tiongkok.

[14] Liputan6. 2020. Cara China tetap Jalani Kerja Sama dengan Indonesia di tengah Pandemi Corona Covid-19. [Online] Retrieved from https://www.liputan6.com/global/read/4269338/cara-Tiongkok-tetap-jalani-kerja-samadengan-indonesia-di-tengah-pandemi-corona-Covid-19\#.

[15] Liputan6. 2021. Ini Dia Daftar Negara Tujuan Ekspor Indonesia, Mana Terbesar? [Online] Retrieved from https://www.liputan6.com/bisnis/read/4532828/ini-dia-daftarnegara-tujuan-ekspor-indonesia-mana-terbesar.

[16] Liputan6. 2020. Paket Bantuan Medis dari Tiongkok untuk Perangi Corona COVID-19 $\begin{array}{lllll}\text { Tiba di Jakarta. } & \text { [Online] } & \text { Retrieved }\end{array}$ https://www.liputan6.com/global/read/4213704/paket-bantuan-medis-dari-Tiongkokuntuk-perangi-corona-Covid-19-tiba-di-jakarta\#.

[17] Cabinet Secretariat of The Republic of Indonesia. 2021. Other Six Million Doses of Vaccine Bulk Arrive in Indonesia. [Online] Retrieved from Sekretariat Kabinet Republik Indonesia: https://setkab.go.id/en/another-six-million-doses-of-vaccine-bulkarrives-in-indonesia/. [Accessed on 22 April 2021].

[18] Republika. 2020. Indonesia Juga Beri Bantuan Perlengkapan Medis ke Tiongkok. [Online] Retrieved from https://www.republika.co.id/berita/q501c4430/indonesia-jugaberi-bantuan-perlengkapan-medis-ke-Tiongkok.

[19] Tempo. 2020. Jokowi Tawarkan Bantuan Tangani Virus Corona ke Cina. [Online] Retrieved from https://nasional.tempo.co/read/1306844/jokowi-tawarkan-bantuantangani-virus-corona-ke-cina.

[20] The Conversation. 2020. Dampak Penting Kesepakatan Indonesia dan Cina untuk Mempromosikan Penggunaan Yuan dan Rupiah. [Online] Retrieved from https://theconversation.com/dampak-penting-kesepakatan-indonesiadan-cina-untuk-mempromosikan-penggunaan-yuan-dan-rupiah.

[21] The Conversation. 2020. Dua alasan mengapa Cina perlu memperbanyak bantuan ke Indonesia untuk penanganan COVID-19, The Conversation. [Online] Retrieved from https://theconversation.com/dua-alasan-mengapa-cina-perlu-memperbanyak-bantuanke-indonesia-untuk-penanganan-Covid-19-136523.

[22] The Ministry of Foreign Affairs of The People's Republic of China. 2021. Strengthen Mutual Support and Create A Better Future Together. [Online] Retrieved from Ministry of Foreign Affairs of the People's Republic of Tiongkok: https://www.fmprc.gov.cn/mfa_eng/wjb_663304/zwjg_665342/zwbd_665378/t184787 1.shtml.

[23] The Ministry of Foreign Affairs of The People's Republic of China. 2020. Ambassador Xiao Qian Attends the Handover Ceremony of Medical Supplies to Indonesia Donated by Chinese Government. [Online] Retrieved from Kedutaan Besar Republik Rakyat 
Tiongkok di Republik Indonesia: http://id.Tiongkokembassy.org/eng/ztbd/112sss/t1787512.htm.

[24] The Ministry of Foreign Affairs of The People's Republic of China. 2020. Chinese and Indonesian Medical Experts Successfully Held 2nd COVID-19 Video Conference. [Online] Retrieved from Kedutaan Besar Republik Rakyat Tiongkok di Republik Indonesia: http://id.Tiongkok-embassy.org/eng/ztbd/112sss/t1777461.htm.

[25] The Ministry of Foreign Affairs of The People's Republic of China. 2020. Chinese and Indonesian Medical Experts Successfully Held 3rd COVID-19 Video Conference. [Online] Retrieved from Kedutaan Besar Republik Rakyat Tiongkok di Republik Indonesia: http://id.Tiongkok-embassy.org/eng/ztbd/112sss/t1786885.htm.

[26] The Ministry of Foreign Affairs of The People's Republic of China. 2020. Chinese and Indonesian Medical Experts Successfully Held COVID-19 Video Conference. . [Online] Retrieved from Kedutaan Besar Republik Rakyat Tiongkok di Republik Indonesia: http://id.Tiongkok-embassy.org/eng/ztbd/112sss/t1772792.htm.

[27] The Ministry of Foreign Affairs of The People's Republic of China. 2020. Chinese and Indonesian Military Medical Experts Successfully Held COVID-19 Video Conference. [Online] Retrieved from Kedutaan Besar Republik Rakyat Tiongkok di Republik Indonesia: http://id.Tiongkok-embassy.org/eng/ztbd/112sss/t1779093.htm.

[28] The Ministry of Foreign Affairs of Republic of Indonesia. 2021. Indonesia dan Tiongkok Sepakat Perkuat Kolaborasi untuk Dorong Pemulihan Ekonomi dan Tangkal Pandemi.

[Online]

Retrieved from https://kemlu.go.id/portal/id/read/2069/berita/indonesia-dan-tiongkoksepakat-perkuat-kolaborasi-untuk-dorong-pemulihan-ekonomi-dan-tangkal-pandemi.

[29] The Ministry of Foreign Affairs of Republic of Indonesia. 2020. Press Briefing Pertemuan Bilateral Menlu RI - Men BUMN RI dengan Menlu Tiongkok, Sanya, 20 Agustus 2020. [Online] Retrieved from Kementerian Luar Negeri Republik Indonesia: https://kemlu.go.id/portal/id/read/1588/view/press-briefing-pertemuan-bilateral-menluri-men-bumn-ri-dengan-menlu-Tiongkok-sanya-20-agustus-2020.

[30] Tiongkokdaily. 2020. Solidarity in a time of adversity. [Online] Retrieved from TIONGKOKDAILY.COM.CN:https://global.Tiongkokdaily.com.cn/a/202007/10/WS5 f07aabfa310834817258713.html.

[31] Tiongkok Embassy.org 2020 Interview: Friendly cooperation between Tiongkok, Indonesia showcased in joint fight against COVID-19: Chinese ambassador, Embassy of the People's Republic of Tiongkok in the Republic of Indonesia. [Online] Retrieved from http://id.Tiongkok-embassy.org/eng/sgdt/t1751479.htm. [Accessed on 21 April 2021].

[32] Umagapi, J. L. 2017. "The Rise of Tiongkok-Indonesia Relationship: Soft Power, Resources, and Prospect in the Future". Indonesian Perspective, 2(2):131.

[33] Vermonte, Philips., Damuri, Yose Rizal., Muhibat, Shafiah. 2020. "Enhancing International and Regional Cooperation to Mitigate the Effects of the COVID-19 Pandemic: A View From Indonesia". Council on Foreign Relations (May 2020):39-41.

[34] Waluyo, S.D., Risman, H. 2020. "Indonesia Defense Diplomacy in Enhancing Indonesia-China Defense Cooperation”. Scholars Journal of Arts, Humanities and Social Sciences 8(12):586-593. 
